\title{
Preparing teachers for the connected learning community
}

\author{
Don Passey \\ Department of Psychology, Lancaster University, Lancaster LAI 4YF, UK. \\ d.passey@lancaster.ac.uk
}

Keywords: strategic plans, national development, ICT strategy, connected learning communities, teacher training needs

Abstract: The United Kingdom (UK) has embarked on an ambitious path - it intends to develop a connected learning community that links and involves schools, libraries, museums, business, industry, and community centres. The first stages of the plans to achieve this vision are laid and being put in place - a strategic vision has been developed, a plan which includes targets and funding for physical resources has been produced, funding and support for teacher training will be available, and resource development on the Internet is under way. The ultimate vision is concerned with the opportunities and abilities that will exist for learning at times in and out of, and in and beyond, school. Curriculum documentation is being put in place to specify the future student, and teacher curriculum (presumably to support this plan). But the mechanisms to support teachers in developing the means to help students learn across and in the school-home-community continuum are not at this stage identified. Is this a basic flaw in the strategy, or a symptom of timely and phased planning?

\section{INTRODUCTION}

The European Commission, in their paper entitled Learning in the Information Society: Action plan for a European education initiative (1996), outlined the concept of a learning society for the European Union (EU). A part of that concept was the belief in the benefits of connecting learners in school with learners in other places. The document stated that "the Commission supports the extension of 'public access' to the Information Society. This includes especially the connection of schools, universities and libraries". The United Kingdom (UK) response to such ideas was to initiate

The original version of this chapter was revised: The copyright line was incorrect. This has been corrected. The Erratum to this chapter is available at DOI: 10.1007/978-0-387-35499-6_29 
a programme of pilot developments, in schools, Local Education Authorities (LEAs), and colleges (DFE 1995b). The results of these pilot developments were evaluated and reported in detail (Scrimshaw 1997). Subsequently, a consultation document, entitled Connecting the Learning Society - National Grid for Learning: The Government's Consultation Paper (DfEE 1997), was produced by the Department for Education and Employment. This outlined the proposed strategy for developing a learning society.

A number of terms have been used to describe the concept of developing a learning society. The term 'connected learning community' is one such term, which contains potentially three different elements that can be separately considered, each one implying something rather different:

- connected community (implies compatible physical links at least);

- learning community (implies some level of agreed purposes for learning, over perhaps a potentially long period of time);

- connected learning (implies some common or agreed purpose and resource).

The challenge for all individuals involved in education is to enable provision for all of these elements. The challenge for those not involved in education is to consider whether involvement would be useful, and how to develop meaningful links. In the case of teachers, they need to develop understandings of what the system might offer, and how it can be used successfully, not just within the school, but also between and across the home, school, and community domain.

\section{WHAT IS NEEDED}

At a strategic or national level, to put into practice such a long term goal, it requires a strategic vision, a strategic plan, and an implementation plan. The Stevenson Report (1997), provided a strategic vision of ICT use in schools, a part of which was a development towards a 'connected learning society'. The report stated that "We wish to see a society within ten years where ICT has permeated the entirety of education (as it will the rest of society) so that it is no longer a talking point but will be taken for granted rather as electricity has come to be". The Superhighways Evaluation Synopsis (Scrimshaw 1997) gathered evidence and reported outcomes from a range of 25 different projects that were implementing aspects of 'connected learning' across the UK, and gave a message that "The notion of a learning institution emphasises the need to change internal relationships and processes ... The notion of the learning community complements this by directing attention towards the ways in which schools or colleges establish links both to other educational institutions and to the local community." 
As a result of these two reports, and others, the UK Department of Education and Employment produced a strategic plan, which was published as a consultation document. The National Grid for Learning Consultation Paper (DfEE 1997) stated that the plan would in part provide for the development of a Grid that would be "a way of finding and using online learning and teaching materials", "a mosaic of inter-connecting networks and education services based on the Internet which will support teaching, learning, training and administration in schools, colleges, universities, libraries, the workplace and home".

So, a strategic vision is set, and a strategic plan is laid. But what of implementation? And what of implementation at the level of the teacher? Already a range of some of the likely needs for implementation by teachers have been identified by a number of authors. For example, Visser and Jain (1997), in a paper on building open learning communities, stated that "While learning is an individualised effort, it is also a social activity. Teaching must be conceived of in terms of a larger social exercise of connecting learners (and, in the process, building communities) to each other and to the world around them. The process of connecting learners involves creating dialogue among diverse groups of learners that allow them to understand and appreciate the differences as well as the similarities that bond us as human beings. This means that teachers must be committed to understanding their learners and the communities that they come from". Cornu (1997), in a paper which considered what teachers will face in terms of implementing future uses of ICT, stated that the experiences in France suggested that teachers will need to accommodate to "the fact that more and more, he (she) will have to manage the access to knowledge, to help students organise the knowledge, hierarchising the knowledge".

The need for teachers to be able to use ICT effectively in schools is a clear need, but their need to be able to support students, parents and the wider community in practices that enable a 'connected learning community' to function are clearly needs that are just as vital, and needs that will be likely to be more difficult to develop, since little practice exists already.

\section{HOME-SCHOOL-COMMUNITY ACTIVITIES}

Evidence shows that children are using ICT at home, often regularly, for educational reasons and educational (Passey 1995; Passey et al. 1997; Sanger et al. 1997). Children use ICT at home, for example, to:

- write stories and poems;

- create works of art and to design materials;

- develop presentations in visual, text, and sound forms, often integrating these forms together; 
- fax and email others to gather information and details;

- access information via the Internet and CD-ROMs.

In many cases these educational pursuits are unrelated to school activities. Parents may be encouraging their children to become involved in such activities, but, again, without reference necessarily to the school situation. Students may take their generated 'home' work into school, but teachers, other than recognising its existence, may do little to further encourage the concept, they do not necessarily capture the potential it offers, and may do little to consider how to utilise possibilities of partnership with the home. In fact, they most often reject its presence since they regard it as being 'elitist' or potentially supporting the 'haves'.

The UK Superhighways Initiative evaluation which focused on homeschool links (Passey et al, 1997) showed a range of positive educational and social benefits and gains for parents, teachers, and students after a short period of use between homes and schools. The study reported that "Resources made available via communications technologies enable students to work on materials at home, and enable parents to support their children in this use. Early findings of outcomes arising from home school link developments suggest that the potential outcomes for further developments of this nature could be significant". Other studies and further studies suggest that this is also the case.

Some schools are beginning to consider the school-home-community domain more strongly. In BEON: Facing the future, a document produced by ICL (1997) following one of the Superhighways Initiative projects, it was stated that "ICT offers new opportunities for schools to extend their partnerships with parents and for involvement with the wider community. Many BEON schools are inviting parents into school to share the achievements of their children through the use of ICT. Some have begun ICT-related evening classes and are positive about the contribution they can make to the lifelong learning of the community". Examples now exist of schools in the UK that offer 'breakfast clubs', which provide access to ICT facilities from 7.30am onwards, with a breakfast, for those who 'have not' the ICT facilities at home. Some schools are asking parents to consider investing in laptop computers, so that students may work with them between home and school (as part of the Microsoft UK supported Anytime Anywhere Learning Project). These are all important initiatives - they not only provide a perspective on a range of possible futures, but they provide also the opportunity for the study of how teachers involve parents, how they encourage learning across the home-school-community domain, and how these teachers reassess their own teaching role and methods.

The need exists for mechanisms to capture the results and outcomes of such experiments, to identify, and to share these with others, so that practice 
can be modelled and developed more widely. The development of ICT practice in schools in the UK has relied, in the past, upon mechanisms to share ideas between schools, and often the ideas have been shared in the absence of a formal mechanism being put in place. The sharing has often, therefore, been ad hoc at best. In this respect our past should enable us to consider the need to build the mechanisms which will serve our present and future needs.

\section{WHAT IMPLEMENTATION IS PLANNED}

Thus far, developments to implement a strategic plan in the UK have focused on four major areas:

- physical resources to link schools and communities, provided through a phased Standards Fund available to state funded schools through the LEAs and the DfEE;

- resources for use across the physical network, being developed by the British Educational Communications and Technology Agency (BECTa);

- a curriculum to state ICT skills and uses appropriate to students (DFE, 1995), in-service teachers (TTA 1998a), and pre-service teachers (TTA 1998b);

- teacher training, to be identified through a needs analysis resource, and to be provided by lottery funded approved training providers.

However, while the physical resources are enabling some potential linking between schools and the wider community to occur, neither the student and teacher curricula, nor the teacher training analysis and training provision account for the needs of teachers to develop mechanisms to support school, home and community learning.

The current student curriculum (DFE 1995a) indicates that students should develop "an ability to use effectively IT tools and information sources to analyse, process and present information, and to model, measure and control external events". While the student requirements go on to say that this should involve "understanding the implications of IT for working life and society", no statement is made of such need to understand the implications for use of IT to support learning between the home, within the community, and for and beyond the school (even while the student is at school). For the lottery funded training programme for in-service teachers, the TTA (1998a) have identified a range of expected outcomes that should arise from that training. While a great deal of attention is paid to pedagogical perspectives on the use of ICT, no attention in this document is paid to the need for teachers to consider the use of ICT to support teaching and learning across a school, home, community domain. Similarly, the preservice teacher curriculum (TTA 1998b) makes no explicit mention of the 
future needs that pre-service teachers might have to support pedagogic practice for teaching and learning in the school, home, community arena.

To develop an ambitious learning society, local, regional, national, and international action will be required.

- Evidence will need to be gathered - about who has what equipment; who uses what applications; about appropriate support to provide.

- Human networks will need to be formed - about who has what interests; who has common concerns and goals.

- Physical equipment may need to be put in place - how 'have nots' will be supported; what resources will provide maximum access; what applications are needed for educational practices.

- Resources will need to be developed - commonly agreed student and teacher curricula; Internet resources to share information and ideas locally, regionally, nationally, and internationally.

In the immediate future, developments and studies of home-schoolcommunity practice should consider and identify:

- the technologies and applications used by students to pursue educational endeavours;

- the place and times when educational endeavour is undertaken;

- the form of educational activities undertaken;

- how teachers manage the learning processes and activities involved (when these are occurring over longer periods of time, or at a distance);

- how teachers encourage appropriate educational activities;

- how parents are involved and supported;

- how parents support students in the home-school-community domain;

- how appropriate learning objectives are set and maintained;

- how appropriate learning outcomes are identified and attained (when technology can be used to 'share' to much greater extents);

- how achievements can be used to better inform others;

- what particular educational benefits and gains result;

- what social benefits and gains result.

Many initiatives being developed currently are likely to be too constrained, in certain ways, to school systems - they do not necessarily consider the need for partnership between home, the community, and schools. Often too little evidence is being gathered to inform initiatives. There are exceptions - the States of Jersey is undertaking an island wide survey of schools, colleges, libraries, and youth facilities to find out about the ICT skills of its educational and education-related employees. The States of Jersey Education Department is also involved in an initiative involving laptop use between a school and homes. Different technological trials are being set up across the island to test out potential solutions for island-wide 
networking. Resources for an island-developed Intranet are being developed. A major programme of training will use a variety of modes of delivery to support all staff employed in education. Accreditation is sought through the European Computer Driving Licence (ECDL), and negotiations are underway to make the ECDL an island-wide qualification available to all its inhabitants. The States government has thus supported and is in the process of producing an ICT strategy that involves all island-dwellers - business and industry, education, social services, and homes. This dynamic development, which considers parallel needs for human networking, physical networking, and resource networking, is concerned with placing the teacher in a position to develop ICT skills dynamically as a part of the learning society development.

\section{CONCLUSIONS}

Being able to harness effectively some of the $85 \%$ of the time that students are not in school (Brighouse 1997), is clearly a notion that has been considered and utilised in the past, since homework is a common prescription of schools for its students. But homework tasks are often discrete and discontinuous elements, related, on occasions, only loosely to work undertaken in lessons in schools. ICT enables us to consider the harnessing of some of the $85 \%$ out-of-school time in different ways:

- through developing a continuity of work between school and home;

- at times to meet the possibilities that students can offer;

- related absolutely to that work which has gone before;

- using the support and involvement of the teacher with others outside the classroom;

- with the support and involvement of parents and the wider community.

So how will teachers be prepared for this need, a need which in many cases already exists? And exactly what are those needs? If 'connected learning communities' are to become a reality, teachers must be prepared for the support of learning between the school, home and the wider community. It will be to our disadvantage to leave this need unattended. If the potential of home and school links is to be harnessed, these needs must be provided for as a part of our equation of teacher development at this time. Even if the details of what to do, and how to do it are not known, at least the concept should be accessible, so that discussion of its potential can be developed.

ICT provides the opportunity for those using it to extend their activities (see Table 1), but since these activities are fundamentally different (at least, initially) for different groups, then teachers face challenges as a consequence. ICT will offer the potential for students to extend their learning by enabling them to focus on their interests to increasing extents, 
and by presenting their work in increasingly diverse ways (in visual, auditory, text, and multi-media forms). The consequences will be that some students will be able to extend their achievements to far greater extents.

Table 1. Extending activities

\begin{tabular}{lll}
\hline Teachers & $\begin{array}{l}\text { can extend their pedagogic } \\
\text { potential }\end{array}$ & $\begin{array}{l}\text { but need to know how to use this at } \\
\text { a distance, in homes and other } \\
\text { environments } \\
\text { but will need to know how and what } \\
\text { learning to apply at different times } \\
\text { budents }\end{array}$ \\
$\begin{array}{l}\text { can extend their learning } \\
\text { potential } \\
\text { can extend their support } \\
\text { potential }\end{array}$ & $\begin{array}{l}\text { and use this support both locally, } \\
\text { and in negotiation with others }\end{array}$ \\
\hline
\end{tabular}

The challenge for teachers will be to manage an increasing diversity, so that students are advantaged - so that those who extend their learning attainments are not limited, and those who could achieve more are set appropriate goals through appropriate learning objectives. Teachers will have the potential to more effectively support students in their own learning environments, perhaps at home, perhaps in the shopping mall, but also to support students in their own learning contexts by providing learning opportunities in their individual areas of interest. A focus on a school-based environment for learning will only give access to and provide for a part of the entire potential - if the full potential is to be gained, the access and use of the entire home-school-community domain must be developed, and the abilities of teachers to utilise it are essential elements for this process.

\section{REFERENCES}

Brighouse, T. (1997) Speech to NCET Seminar, Coventry, UK. 27 February 1997.

Cornu, B. (1997) Teachers and teacher education facing information and communications technologies. In D. Passey and B. Samways (eds.) Information Technology: Supporting Change Through Teacher Education. London: Chapman and Hall.

DFE (1995a) Information Technology in the National Curriculum. London: Department For Education.

DFE (1995b) Superhighways for Education: The Way Forward. London: Her Majesty's Stationery Office.

DfEE (1997) Connecting the Learning Society: National Grid for Learning. The Government's Consultation Paper. London: Department for Education and Employment.

European Commission (1996) Learning in the Information Society: Action Plan for a European Education Initiative. (1996-98). Brussels: EU.

Passey, D. (1995) An Evaluation Study of Teletutoring Methods at Open School, and the Potential for its Further Development in the Education and Support of Children in a Range of Situations and Locations: The Report. Totnes, UK: Open School. 
Passey, D., Forsyth, K., Hutchison, D., Scott, A., and Williams, N. (1997) Group D Evaluation of the Projects Focusing Mainly on Home-School Links. Coventry, UK: National Council for Educational Technology.

Sanger, J., Wilson, J., Davies, B., and Whittaker, R. (1997) Young Children, Videos and Computer Games: Issues for Teachers and Parents. London: Falmer Press.

Scrimshaw, P. (1997) Preparing for the Information Age: Synoptic Report of the Education Departments' Superhighways Initiative. London: Department for Education and Employment.

Still, M. and Sharp, J. (1997) BEON: Facing the Future. Bristol, UK: ICL Education Systems.

The Independent ICT in Schools Commission (1997) Information and Communications Technology in UK Schools: An Independent Enquiry. London: The Independent ICT in Schools Commission.

TTA (1998a) New Opportunities Fund. The Use of ICT in Subject Teaching. London: Her Majesty's Stationery Office.

TTA (1998b) Initial Teacher Training National Curriculum for The Use of Information and Communications Technology in Subject Teaching. London: Her Majesty's Stationery Office.

Visser, J. and Jain, M. (1997) Towards building open learning communities: Recontextualising teachers and learners. In D. Passey and B. Samways (eds.) Information Technology: Supporting Change Through Teacher Education. London: Chapman and Hall.

\section{ACKNOWLEDGEMENT}

My thanks to Simone Kennett, States of Jersey Education Department, for her kindness in offering comments on an earlier draft of this paper.

\section{BIOGRAPHY}

Don Passey has undertaken number of evaluations and research projects, looking at the uses and outcomes of ICT in primary and secondary education, and has worked as a consultant to government agencies, commercial companies, and individual schools $\mathrm{He}$ led one of the Superhighways evaluation teams, which looked at the potential development and uses of communication technologies in home and school situations, and is currently leading an evaluation team that is looking at the implementation and learning outcomes of the Anytime Anywhere Learning Programme in the UK and the States of Jersey. 